AUSTRALIAN JOURNAL OF BASIC AND
APPLIED SCIENCES
$\begin{aligned} & \text { ISSN:1991-8178 } \\ & \text { EISSN: 2309-8414 } \\ & \text { DOI: } 10.22587 / a j b a s .2017 .11 .13 .15 \\ & \text { Journal home page: www.ajbasweb.com }\end{aligned}$

\title{
Induced Photo degradation of Poly (Vinyl Chloride) by Some Metal Complexes with Schiff Base
}

\author{
${ }^{1}$ Amir. Dawood, ${ }^{2}$ Ahmed A. Ahmed, ${ }^{3}$ Suha B. Aliwy \\ ${ }^{I}$ Amir. Fahdil. Dawood AL-Niaimi, Pro(Dr) Department of Chemistry, College of Science, Diyala University, Baquba, Diyala, Iraq. \\ ${ }^{2}$ Ahmed A. Ahmed Polymer Research Unit, College of Science, AL-Mustansirya University, Baghdad, Iraq. \\ ${ }^{3}$ Suha B. Aliwy, Department of Chemistry, College of Science, University Diyala, Baquba, Diyala, Iraq.
}

\section{Address For Correspondence:}

Prof.(Dr) Amir.Fahdil, Dawood AL-Niaimi,Dep. Chemistry, College of Science ,University of Diyala, Baquba, Diyala, Iraq.

E-mail:dr_amer44@yahoo.com

\section{ART I CLE INFO}

Article history:

Received 12 October 2017

Accepted 22 November 2017

Available online 6 December 2017

Keywords:

Poly(vinyl chloride), Photo

degradation, photosensitized, Loss weight

\begin{abstract}
A B S T R A C T
In this paper, the photo degradation ofPVC films by Schiff base[(z)-2((2-Aminoethyl) imino)-1,2-diphenylethanol)](AIDOH)with $\quad \mathrm{Sn}^{(11)}, \mathrm{Mn}^{(11)}, \mathrm{Ni}^{(11)}, \mathrm{Cd}^{(11)}$, and $\mathrm{Zn}^{(11)}$ complexes was investigated. The PVC films containing concentration of compounds $0.05 \%$ by weight $(80 \mu \mathrm{m}$ thickness) were produced by casting method from tetrahydrofuran (THF) solvent. The photo degradation activities of these compounds were determined by monitoring the carbonyl, hydroxyl and polyene indices with irradiation time also calculating the photo degradation rate constant (kd) for PVC films with and without additives. the change in viscosity average molecular weight and measuring the weight loss of PVC films were also followed with irradiation time (using THF solvent). The photo degradation efficiency of the investigated photodegraded was found to follow this order:

$\mathrm{Zn}(\mathrm{AIDO})_{2}>\mathrm{Ni}(\mathrm{AIDO})_{2}>\mathrm{Mn}(\mathrm{AIDO})_{2}>\mathrm{Sn}(\mathrm{AIDO})_{2}>\mathrm{Cd}(\mathrm{AIDO})_{2}>\mathrm{PVC}$
\end{abstract}

\section{INTRODUCTION}

The photosensitized degradation of polymer system is occasionally used as a means of solving the problem of environmental pollution by plastic litter. The attempts to develop plastics with reduced outdoor stability are based on (Ranbyetal., 1975; Rabek., 1994; Amir., 1999):

(i)Syntheses of polymers with light -sensitive groups, eg; aliphatic ketone groups located predominantly in the main chain or in pendant (side) groups.

(ii)Modification of polymers by addition of another polymer.

(iii)Application of photosensitizes which are added to polymers or plastic to photosensitize their degradation process.

A number of research papers have appeared in literature dealing with the photosensitized degradation of polymers by addition of transition - metals salts and complexes (Amir.1999). Polyvinyl chloride (PVC), is one of the most versatile polymers and is the third largest produced polymer in the world (Fischeretal, 2014; Yousif,etal., 2015). The low cost and good performance of poly(vinyl chloride) (PVC) products have increased the utilization of this polymer in building, mainly in exterior application, such as window profiles, cladding structures, and siding However, ultimate user of PVC products for outdoor building applications depends on their ability to resist photo degradation over long periods of sunlight exposure (Coghlan.,2001).

However, PVC suffers from poor thermal and light stability. It undergoes rapid autocatalytic dehydro chlorination upon exposure to heat and light during its molding and use (Yousif etal.,2016).In recent years, the use of polymeric materials has rapidly increased, but it is well established that rapidphoto degradation of these materials is possible when they are exposed to natural weathering (Yousif.,(2012).To ensure the weather ability of these materials, the PVC resin needs to be compounded and processed properly using suitable additives,

Open Access Journal

Published BY AENSI Publication

(C) 2017 AENSI Publisher All rights reserved

This work is licensed under the Creative Commons Attribution International License (CC BY). http://creativecommons.org/licenses/by/4.0/ 
leading to a complex material whose behavior and properties are quite different from the PVC resin by itself. It is well known that all commonly used plastics degrade under the influence of sunlight. Thus, all synthetic polymers require stabilization material to deter the adverse effects. It is necessary to find ways to prevent, or at least reduce the damage caused by the environmental parameters such as light, air and heat. The photo stabilization of polymers involves the retardation or elimination of photochemical process in polymers and plastics that occurs during irradiation. The following stabilizing systems have been developed which depend on the actions of stabilizers: (a) light screeners, (b) UV absorbers, (c) excited state quenchers, (d) peroxide decomposers and (e) radical scavengers (Hamid., 2000). In this paper, the photosensitization of the photo degradation process of PVC films by as possible additive for the enhancement of the photo degradation of PVC will be described.

\section{MATERIALS AND METHOD}

All starting Materials to prepared complexes (additions of PVC) were purchased commercially and used without further purification.

\section{Synthesis of Schiff base [(Z)-2-((2-aminoethyl) imino)-1,2-diphenylethanol)]:}

To a hot ethanoic solution of benzoin $(0.02 \mathrm{~mol}, 4.24 \mathrm{~g})$ and ethylene diamine $(0.02 \mathrm{~mol}, 1.2 \mathrm{~g})$ was added some drops of glacial acetic acid and the mixture refluxed for 3 hours. The hot solution was cooled into room temperature upon orange precipitate of the Schiff's base separated: it was filtered. Washed with water, dried and recrystallized from glacial acetic acid (-Aliyu and Abdullahi,. 2009).

\section{Synthesis of $\mathrm{Cd}(\mathrm{II}), \mathrm{Ni}(\mathrm{II}), \mathrm{Sn}(\mathrm{II}), \mathrm{Zn}(\mathrm{II})$ and $\mathrm{Mn}(\mathrm{II})$ complexes:}

All the complexes were prepared by the same procedure: A hot ethanoic solution of the ligand of $(\mathrm{Z})-2-((2-$ aminoethyl)imino)-1,2-diphenylethanol $(\mathrm{AIDOH})(0.001 \mathrm{~mol})$ in absolute ethanol $(10 \mathrm{ml})$ was prepared and then $\left(\mathrm{SnCl}_{2} \cdot \mathrm{MnCl}_{2} \cdot \mathrm{ZnCl}_{2} \cdot \mathrm{NiCl}_{2} \cdot 6 \mathrm{H}_{2} \mathrm{O}\right.$ and $\left.\mathrm{Cd}\left(\mathrm{NO}_{3}\right)_{2} \cdot 4 \mathrm{H}_{2} \mathrm{O}\right)(0.0005 \mathrm{~mol})$ in absolute ethanol $(10 \mathrm{ml})$ was added to the hot solution of AIDOH ligand. The mixture of ligand and metal halide were refluxed for 2 hrs. The product colored solution was left standing at room temperature to crystallize. The product was filtered to obtain precipitate washed with cooled absolute ethanol. Recrystallized from methanol: glacial acetic acid (1:1) then dried (Nuhaand Firas., 2016). The structures of the Schiff base and their complexes are given below (figure 1).
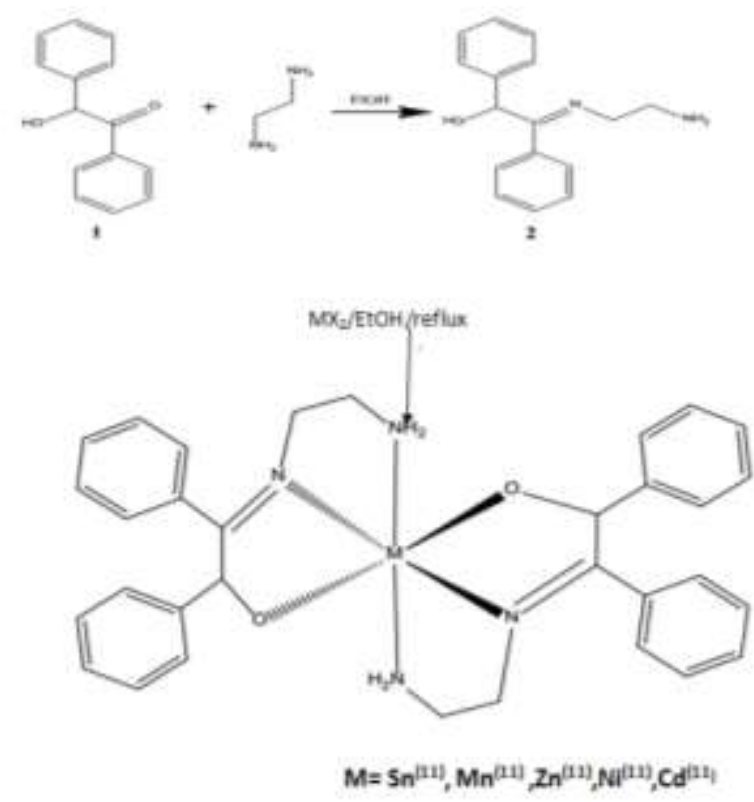

Fig. 1: Preparative method for Schiff base [(Z)-2-((2-aminoethyl)imino)-1,2-diphenylethanol)] and its complexes

\section{Experiment AL techniques:}

I) Films preparation:

A solution of Poly(vinyl chloride) solution or modified Poly(vinyl chloride) $(5 \mathrm{~g} / 100 \mathrm{ml})$ in tetrahydrofuran was used to prepare $(80 \mu \mathrm{m})$ thickness of polymer films, (measured by a micrometer type 2610 A, Germany). The films were prepared by evaporation technique at room temperature for 24 hours. To remove the possible 
residual tetrahydrofuran solvent, film samples were further dried at room temperature for three hours under reduced pressure (Bottino et al.,2004).

\section{II) Irradiation Experiments:}

UV- Light was used for irradiation polymer films, giving wavelength range between (250 to $380 \mathrm{~nm}$ ) and

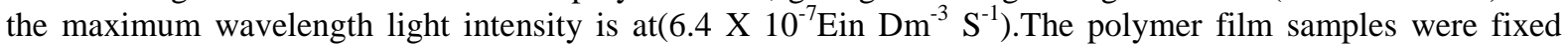
parallel to each other and the lamp of the UV. Incident radiation is vertically incident on the samples. The distance between the polymer films and the source was $(10 \mathrm{~cm})$. The polymer film samples were vertically fixed parallel to the lamps to make sure that the UV incident radiation is perpendicular to the samples. The irradiated samples were rotated from time to time to ensure that the intensity of light incident on all samples is the same(Shriner and Hermann., 2004).

\section{III) Photo degradation Measuring Methods:}

A- Measuring the Photo degradation Rate of Polymer Films Using Infrared Spectrophotometry:

Infrared spectrophotometer -4200 JASCO was used for monitoring the growth of carbonyl and hydroxyl and polyene groups at $\left(1770,3460,1629 \mathrm{~cm}^{-1}\right)$ respectively, in order to eliminate the effect of sample thickness we adopted the band indexing method .A band index(Ranbyetal.,1975) is defined as $I_{s}=A_{s} / A_{r}$, where $A_{s}$ is the absorbance of the studied band and $A_{r}$ is the absorbance of the reference band at $1328 \mathrm{~cm}^{-1}$. Actual absorbance ,the difference between the absorbance of top peak and the base line (A Top peak-A Base line),is calculated using the base line method(Harris and Kratochvil., 1981).

\section{B. Measuring the Photo degradation Rate of Polymer Films Using Ultraviolet-Visible Spectrophotometer:}

Ultraviolet-visible spectrophotometry technique was used to measure the changes in the UV-Visible spectrum during different irradiation times for each polymer film at maximum absorption band $(\lambda \max =200$ $400 \mathrm{~nm})$. The photo degradation rate constant for the PVC films $\left(\mathrm{k}_{\mathrm{d}}\right)$ was calculated using the first order kinetic equation

$\ln (\mathrm{a}-\mathrm{x})=\ln \mathrm{a}-\mathrm{k}_{\mathrm{d}} \mathrm{t}$

where $: \mathrm{a}=$ the additive concentration before irradiation

$\mathrm{x}=$ the additive concentration after irradiation time ( $\mathrm{t}$ in sec).

If $\mathrm{A}_{\mathrm{o}}$ represents the absorption intensity of the polymer film containing additive before irradiation, $\mathrm{A} \infty$ intensity at infinite irradiation time and At is the absorption intensity represents the absorption after irradiation time t, then:

$\mathrm{a}=\mathrm{A}_{\mathrm{o}}-\mathrm{A}_{\infty} \quad ; \mathrm{x}=\mathrm{A}_{\mathrm{o}}-\mathrm{A}_{\mathrm{t}}$

$a-x=A_{o}-A \infty-A_{o}+A_{t}=A_{t}-A_{\infty}$

Substitution of (a) and (a-X) from equations (2) in (1) gives:

$\ln \left(\mathrm{A}_{\mathrm{t}}-\mathrm{A}_{\infty}\right)=\ln \left(\mathrm{A}_{\mathrm{o}}-\mathrm{A}_{\infty}\right)-\mathrm{kdt}$

Thus the plot of $\ln \left(A_{1}-A_{\infty}\right)$ versus irradiation time (t) gives straight line with a slope equal to (-kd). This indicates that photodecomposition of the additive in first order (Amir.,1999).

\section{C) Measuring the Photo degradation by Weight Loss:}

The Photo degradation efficiency was determined by measuring the $\%$ weight loss of photodegraded PVC films in absence and in presence of additives by applying the following equation: Weight loss $\%=\left[\left(\mathrm{W}_{1}-\mathrm{W}_{2}\right) / \mathrm{W}_{1}\right] 100$

Where $\mathrm{W}_{1}$ is the weight of the original sample (before irradiation), and $\mathrm{W}_{2}$ is the weight of the sample (after irradiation) (Gugumns., 1979).

\section{D)Determination of Viscosity average Molecular Weight $\left(\dot{M}_{v}\right)$ Using Viscometry:}

The viscosity property was used to determine the average molecular weight of polymer using the MarkHouwink relation (Amir.,1999; Sabaa et al., 2006).

$[\eta]=\mathrm{K} \mathrm{M}_{\mathrm{V}}^{\alpha}$

[n] is the intrinsic viscosity, $\mathrm{k}$ and $\alpha$ are constant dependent upon the polymer-solvent system at a particular temperature.

The single -point measurements were converted to intrinsic viscosities by $\mathrm{Eq}(6)$

$[\eta]=(\sqrt{2 /} \mathrm{c})\left(\eta_{\mathrm{sp}}-\ln \eta_{\mathrm{re}}\right)^{1 / 2}$ 
$\mathrm{C}=$ concentration of polymer solution $(\mathrm{g} / 100 \mathrm{ml})$.By applying $\mathrm{Eq}(5)$, the molecular weight of degraded and un degraded polymer can be calculated .Molecular weight of PVC with and without additives were calculated from intrinsic viscosities measured in THF solution using the following equation:

$[\eta]=1.38 \times 10^{-4} \mathrm{Mv}^{0.77}$

The quantum yield of main chain scission $\left(\varphi_{\mathrm{cs}}\right)$ was calculated from viscosity measurement using the following equation:

$\Phi_{\mathrm{cs}}=(\mathrm{C} \mathrm{A} / \mathrm{Mv}, \mathrm{O})\left[\left(\left[\mathrm{n}_{\mathrm{O}}\right] /\left[\eta^{1 / \alpha}\right]^{1 / \alpha}-1\right] / \mathrm{I}_{0} \mathrm{t}\right.$

Where $\mathrm{C}=$ concentration, $\mathrm{A}=\mathrm{Avogadro}$ ' number, $\mathrm{Mv},_{\mathrm{O}}$ the initial viscosity-average molecular weight, $\left[\eta_{0}\right]$ and $[\eta]=$ intrinsic viscosity of polymer before and after irradiation respectively, $\alpha=$ exponent in the relation $5, \mathrm{l}=$ incident intensity and $\mathrm{t}=$ irradiation time in seconds.

\section{RESULTS AND DISCUSSION}

\section{Measuring the Photo degradation Rate of Polymer Films Using Ultraviolet-Visible Spectrophotometer:}

Ultraviolet radiations are known to have deleterious effects on most industrial polymers inducing chemical modification and scission of polymer chain, which ultimately lead to an undesirable loss of the mechanical and surface properties of the irradiated material(-Yusop.,2014). Poly (vinyl chloride) suffers from poor thermal and light stability. The prepared metal compounds were used as photodegraded to Poly (vinyl chloride) films comparing with Poly (vinyl chloride) films (blank). The physical properties of additives and polymers play a very important role in determining the additive efficiency in photo stabilization or photo degradation of polymers (Sabaa etal2006). The additives used in this study were chosen to be completely soluble in polymer solvent, THF. Thus the photodecomposition rate constant $\left(\mathrm{k}_{\mathrm{d}}\right)$ was calculated. The $\left(\mathrm{k}_{\mathrm{d}}\right)$ values were computed using the UV spectra changes of PVC films thickness $(80 \mu \mathrm{m})$ containing $0.05 \mathrm{w} / \mathrm{W}$ of additives. The plot of irradiation time versus $\ln (\mathrm{At}-\mathrm{A} \infty)$, gives straight line which indicates primarily the first order reaction. The slope equal to the decomposition rate constant $\mathrm{k}_{\mathrm{d}}$. The values of the first order rate constant of all the additives decay in PVC films $\left(\mathrm{k}_{\mathrm{d}}\right)$ calculated by the same way and shown in Table (1).

Table 1: Photodecomposition Rate Constant $(\mathrm{kd})$ of PVC Films $(80 \mu \mathrm{m})$ Thickness Containing $(0.05)$ w/w of Additives.

\begin{tabular}{|c|c|}
\hline $\mathrm{K}_{\mathrm{d}}\left(\mathrm{hr}^{-1}\right)$ & Additives \\
\hline 0.004 & $\mathrm{PVC}($ blank $)$ \\
\hline 0.006 & $\mathrm{Cd}(\mathrm{AIDO})_{2}$ \\
\hline 0.009 & $\mathrm{Sn}(\mathrm{AIDO})_{2}$ \\
\hline 0.012 & $\mathrm{Mn}(\mathrm{AIDO})_{2}$ \\
\hline 0.015 & $\mathrm{Ni}(\mathrm{AIDO})_{2}$ \\
\hline 0.017 & $\mathrm{Zn}(\mathrm{AIDO})_{2}$ \\
\hline
\end{tabular}

The photodegraded always possess high $\mathrm{k}_{\mathrm{d}}$ values, which mean that these modified polymers are unstable towards UV light.

\section{Measuring of the Photo degradation Efficiency for Poly(vinyl chloride)Films by Weight Loss Method:}

The photo degradation of Poly (vinyl chloride) is commonly known to be accompanied by a dehydro chlorination process (the evolution of $\mathrm{HCl}$ gas); consequently, weight loss occurs, which increases with the increasing of irradiation time. Thus, the weight-loss percentage as a function of the irradiation time can be a good measure of the degree of degradation and consequently can measure the induce potency of the inducer photo degradation. Weight loss measurements were carried out according to the equation (4).

The results of the weight loss as a function of the irradiation time are shown in Fig(2). This results clearly show the low extent of weight loss (i.e., the low extent of dehydro chlorination as evolved $\mathrm{HCl}$ is the main degradative product) of photodegraded Poly (vinyl chloride) degradation by the compounds in comparison with the weight loss of photodegraded of PVC (Braunetal 2011). The rate of the degradation of the blank PVD film(control)was slower than its containing additives. Thus the degradation efficiency of the investigated photodegraded was found to follow this order:

$$
\mathrm{Zn}(\mathrm{AIDO})_{2}>\mathrm{Ni}(\mathrm{AIDO})_{2}>\mathrm{Mn}(\mathrm{AIDO})_{2}>\mathrm{Sn}(\mathrm{AIDO})_{2}>\mathrm{Cd}(\mathrm{AIDO})_{2}>\mathrm{PVC}
$$


Amir. Dawood et al, 2017 I Tr

Australian Journal of Basic and Applied Sciences, 11(13) November 2017, Pages: 128-135

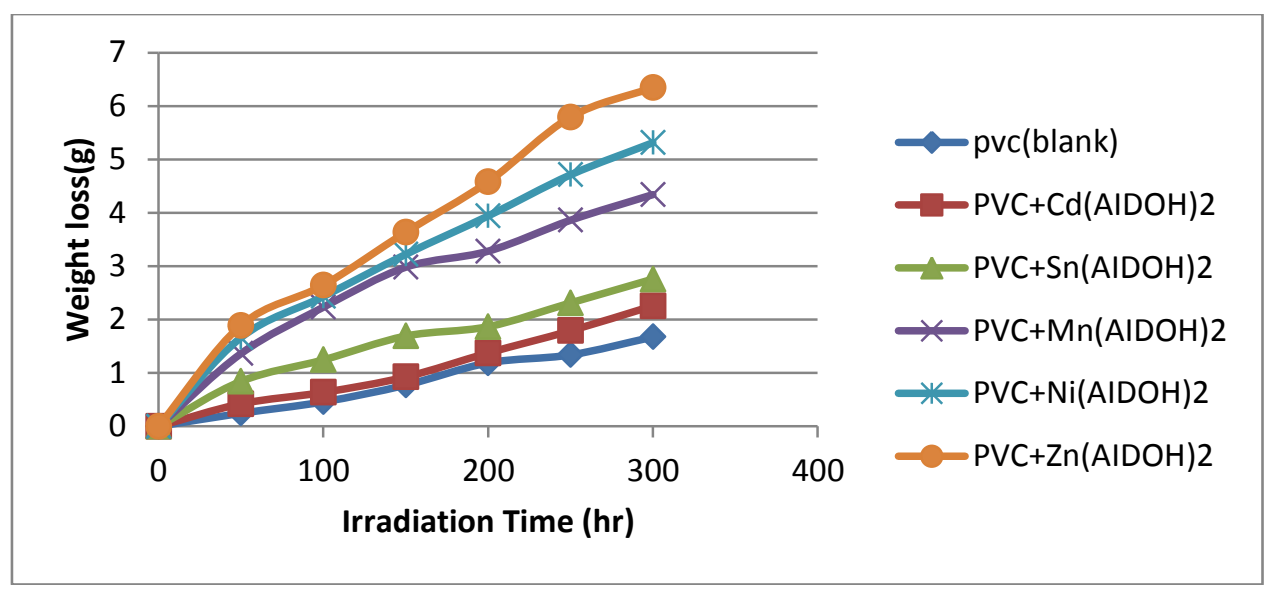

Fig. 2: Variation of the weight loss of PVC films $(80 \mu \mathrm{m})$ thickness containing $0.05 \mathrm{w} / \mathrm{w}$ additives with the irradiation time.

\section{Measuring the Photo degradation Rate of Polymer Films Using Infrared Spectrophotometry:}

The irradiation of PVC films led to a clear change in their FTIR spectra, Appearance of bands in $1770 \mathrm{~cm}^{-1}$ and $1724 \mathrm{~cm}^{-1}$ was attributed to the formation of carbonyl groups related to chloroketone and to aliphatic ketone, respectively. A third band was observed at $1629 \mathrm{~cm}^{-1}$ was related to polyene group .a band at $3440 \mathrm{~cm}^{-1}$ attributed to hydroxyl group. The absorption of the carbonyl, hydroxyl and polyene groups is used to follow the extent of polymer degradation during irradiation. This absorption was calculated as carbonyl index $\left(l_{\mathrm{CO}}\right)$, polyene index $\left(\mathrm{l}_{\mathrm{PO}}\right)$ and hydroxyl index $\left(\mathrm{l}_{\mathrm{OH}}\right)$ are calculated with irradiation time. The effectiveness of this complexes on the rate photo degradation of PVC films was monitored by following the $\left(\mathrm{I}_{\mathrm{CO}}\right)$, $\left(\mathrm{I}_{\mathrm{PO}}\right)$ and $\left(\mathrm{I}_{\mathrm{OH}}\right)$ with irradiation time. Results shown in figs (3-5). Since the growth of $\left(\mathrm{I}_{\mathrm{CO}}\right),\left(\mathrm{I}_{\mathrm{PO}}\right)$ and $\left(\mathrm{I}_{\mathrm{OH}}\right)$ with irradiation time is higher than PVC control, illustrate that complexes are active in sensitization of the photo degradation processes. Therefore, the $\mathrm{Zn}(\mathrm{AIDO})_{2}$ is the most active photosensitizer, followed by Ni (AIDO) ${ }_{2} \mathrm{Mn}(\mathrm{AIDO})_{2} \operatorname{Sn}(\mathrm{AIDO})_{2}$ and $\mathrm{Cd}(\mathrm{AIDO})_{2}$.

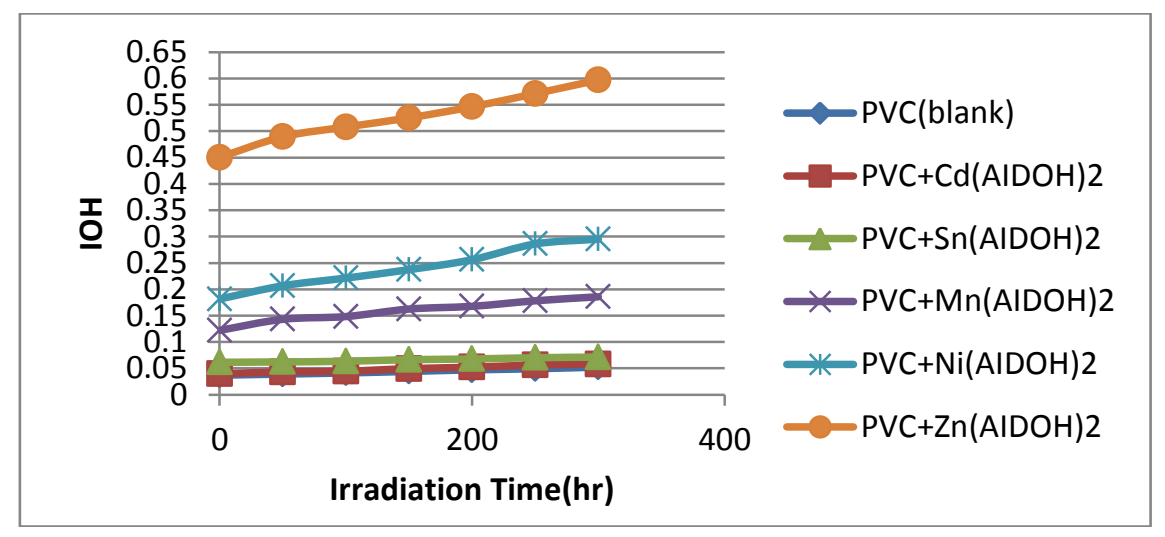

Fig. 3: Change in hydroxyl index and irradiation time $P V C$ films $(80 \mu m)$ thickness containing $0.05 \mathrm{w} / \mathrm{w}$ additives 


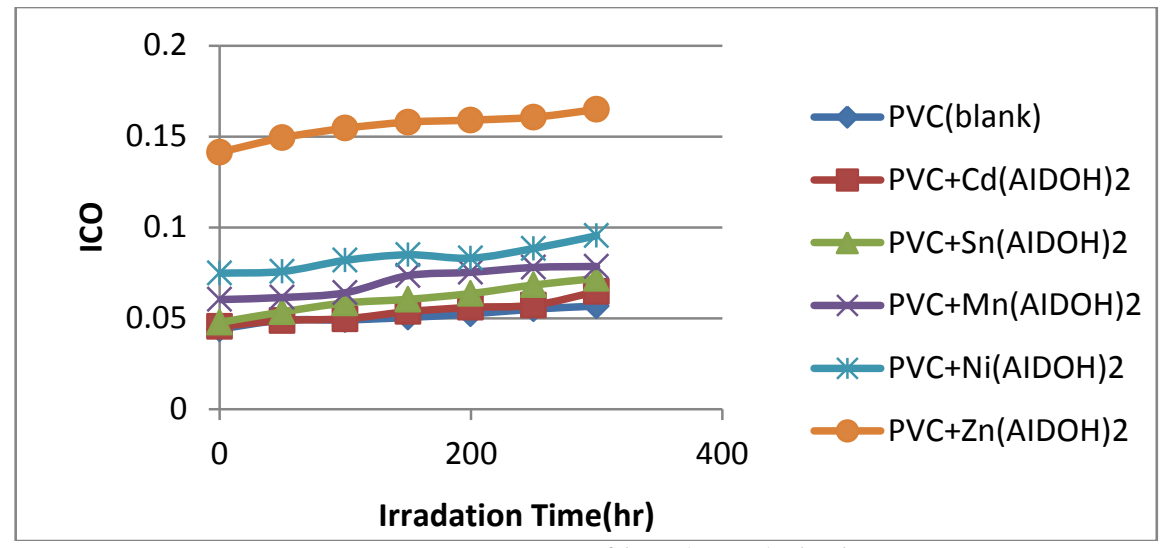

Fig. 4: Change in carbonyl index and irradiation time $P V C$ films $(80 \mu m)$ thickness containing $0.05 \mathrm{w} / \mathrm{w}$ additives

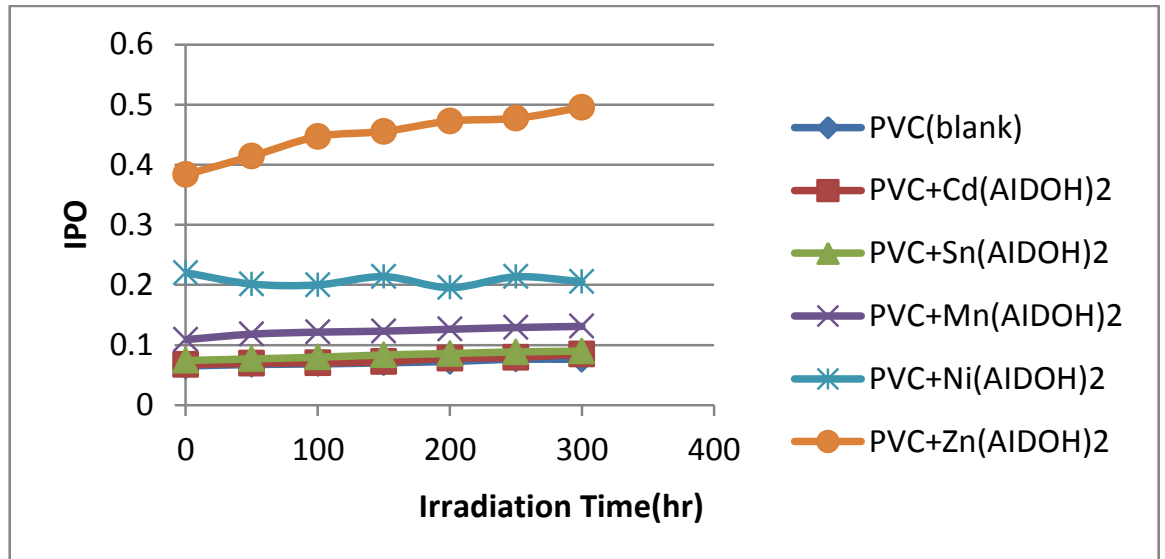

Fig. 5: Change in polyene index and irradiation time $P V C$ films $(80 \mu \mathrm{m})$ thickness containing $0.05 \mathrm{w} / \mathrm{w}$ additives

\section{Variation in PVC Molecular Weight During Photolysis:}

Figure 6 shows the plot of(Mv) versus irradiation time for PVC film with and without additive. The average chain scission number (average number cut per single chain) (s) was calculated using equation (9). $\mathrm{S}=\left(\mathrm{M}_{\mathrm{V}, \mathrm{O}} / \mathbf{M}_{\mathrm{V}, \mathrm{T}}\right)-1$

Where $\mathrm{M}_{\mathrm{V}, \mathrm{O}}$ and $\mathrm{M}_{\mathrm{V}, \mathrm{T}}$ are viscosity average molecular weight at( zero and $\mathrm{t}$ ) irradiation time, respectively ..The plots of $\mathrm{S}$ versus time is shown in figure 7.For randomly distributed weak bond links, which break rapidly in the initial stages of photo degradation ,the degree of deterioration as a function of irradiation is shown in figure 8.Another way of degradation reaction characterization is the measurement of the quantum yield of the chain scission ( $\varphi c s)$, the $(\varphi c s)$ values are tabulated in table 2.

The ( $\varphi c s)$ values for PVC films in the presence additive are more than those of additive -free PVC (control).

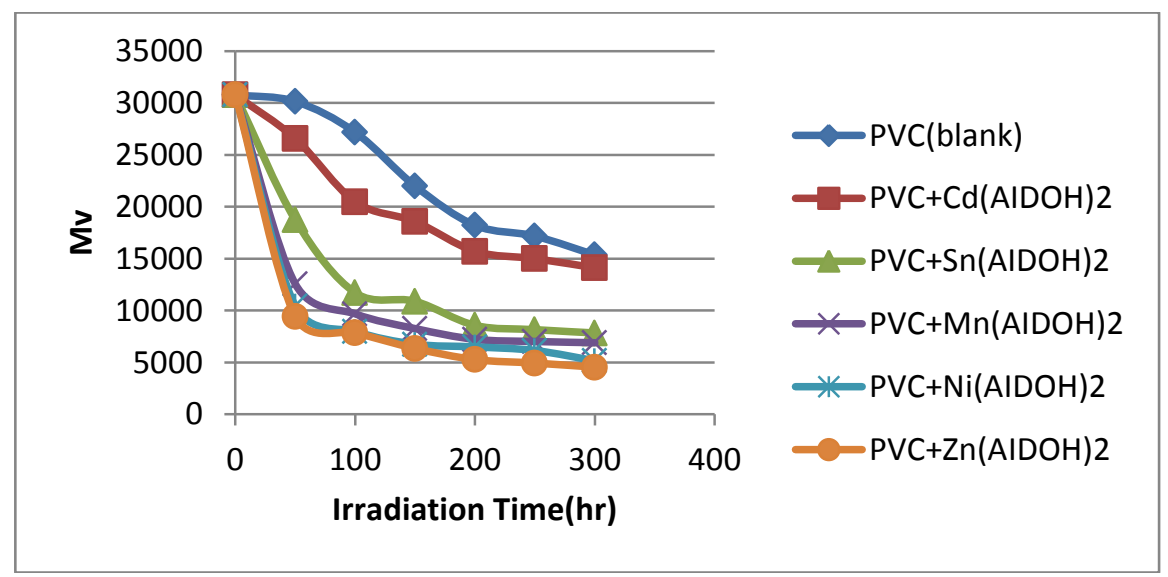

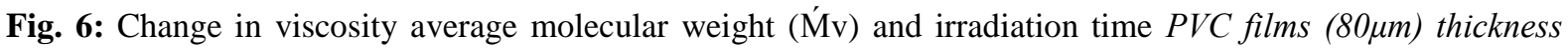
containing $0.05 \mathrm{w} / \mathrm{w}$ additives 
Amir. Dawood et al, 2017) 1 క

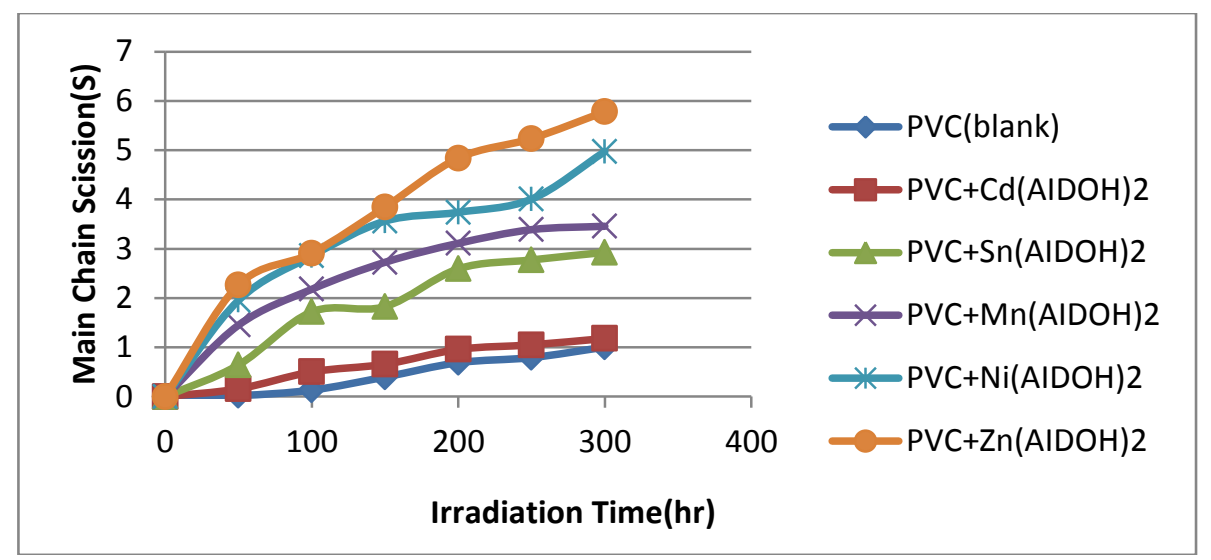

Fig. 7: Change in main chain scission (s) and irradiation time PVC films $(80 \mu m)$ thickness containing $0.05 \mathrm{w} / \mathrm{w}$ additives

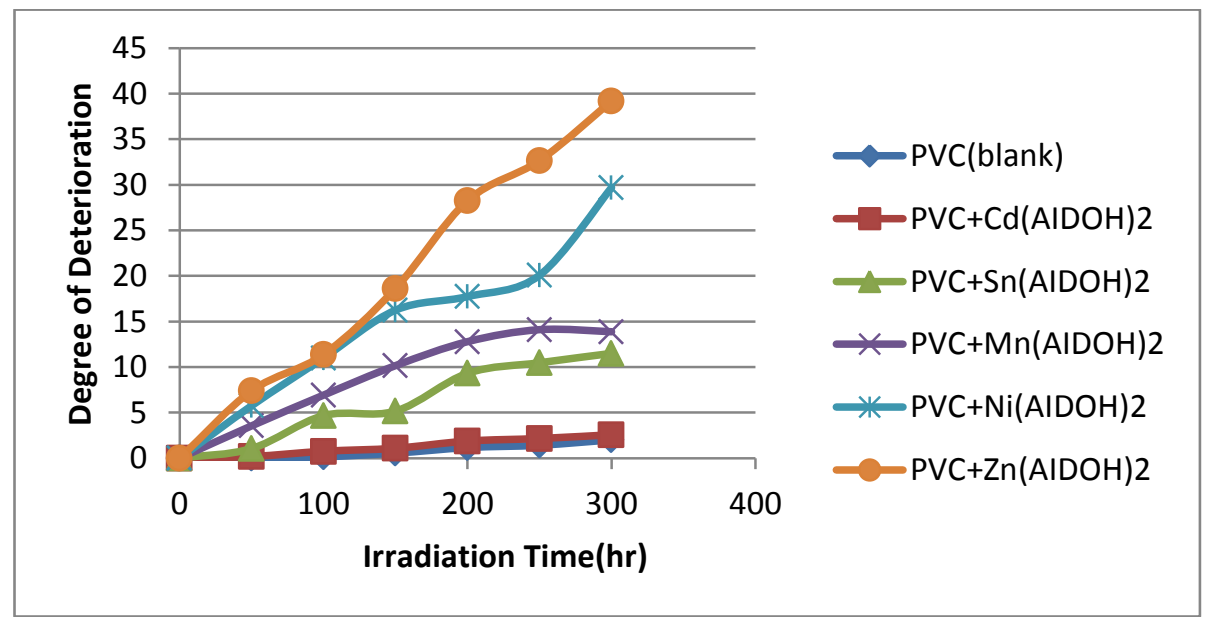

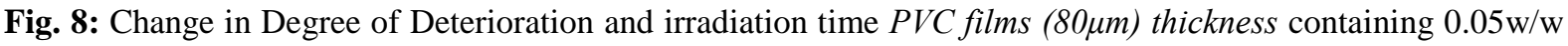
additives

Table 2: Quantum yield (Фcs) for the chain scission for PVC film $(80 \mu \mathrm{m})$ thickness containing $0.05 \mathrm{w} / \mathrm{w}$ additives

\begin{tabular}{|l|l|}
\hline Additives & Quantum Yield $\left(\Phi_{\mathrm{cs}}\right)^{19}$ \\
\hline $\mathrm{PVC}($ blank $)$ & $1.89 \times 10^{19}$ \\
\hline $\mathrm{PVC}+\mathrm{Cd}(\mathrm{AIDO})_{2}$ & $3.11 \times 10^{19}$ \\
\hline $\mathrm{PVC}+\mathrm{Sn}(\mathrm{AIDO})_{2}$ & $7.98 \times 10^{19}$ \\
\hline $\mathrm{PVC}+\mathrm{Mn}(\mathrm{AIDO})_{2}$ & $9.14 \times 10^{19}$ \\
\hline $\mathrm{PVC}+\mathrm{Ni}(\mathrm{AIDO})_{2}$ & $1.49 \times 10^{20}$ \\
\hline $\mathrm{PVC}+\mathrm{Zn}(\mathrm{AIDO})_{2}$ & $1.71 \times 10^{20}$ \\
\hline
\end{tabular}

\section{Conclusion:}

Addition of the Schiff base [(z)-2((2-Aminoethyl)imino)-1,2-diphenylethanol)] (AIDOH) with $\mathrm{Sn}^{(11)}, \mathrm{Mn}^{(11)}, \mathrm{Ni}^{(11)}, \mathrm{Cd}^{(11)}$, and $\mathrm{Zn}^{(11)}$ complexes to $\mathrm{PVC}$ films $(0.05 \mathrm{~W} / \mathrm{W}, 80 \mu \mathrm{m}$ thickness $)$, have successfully worked as induce photo degradation PVC films. The Photo degradation activities of these compounds were monitoring by many methods the carbonyl, hydroxyl and polyene indices, calculating the photo degradation rate constant (kd) for PVC films with and without additives ,the change in viscosity average molecular weight and measuring the weight loss of PVC films were also followed with irradiation time (using THF solvent). The degradation efficiency of the investigated photodegraded was found to follow this order:

$\mathrm{Zn}(\mathrm{AIDO})_{2}>\mathrm{Ni}(\mathrm{AIDO})_{2}>\mathrm{Mn}(\mathrm{AIDO})_{2}>\mathrm{Sn}(\mathrm{AIDO})_{2}>\mathrm{Cd}(\mathrm{AIDO})_{2}>\mathrm{PVC}$

\section{REFEERENCES}

Ranby, B. and J.F. Rabek, 1975. Photo degradation ,Photo oxidation and Photostabilisation of Polymer,Wiley Inter science, London.

Rabek, J.F., 1994. Polymer Photo degradation Mechanisms and Experimental Methods Stocholm. 
Amir, F.D. AL-Niaimi, 1999. Ph.D.Thesis. University of Mustansirya, College of Science.

Fischer, I., W.F. Schmitt, H.C. Porth, M.W. Allsopp and G. Vianello, 2014. Poly (Vinyl Chloride).Ullmann's Encyclopedia of Industrial Chemistry.

Yousif, E., J. Salimon and N. Salih, 2015. New Photo stabilizers For PVC Based on Some Diorgano tin (IV) Complexes. Journal of Saudi Chemical Society, 19(2): 133-141.

Coghlan, P.A., 2001. Discussion of Some the Scientific Issues Concerning the Use of PVC. CSIRO Molecular Science, Australian National University.

Yousif, E., H. Raghad, H.Y. Badrul, A. Syazwan, Z.A. Noraziani, O. Hazreen, K. Afiga, Z.H. Hasniza, M. Bashar and I.Z. Saiful, 2016. Induced Photo degradation Effect on The Functionalized Fe ${ }^{(111)}$ Complex AdditivePoly(Vinyl Chloride) Thin Film., Journal Teknologi, 78(7): 91-97.

Yousif, E., 2012. Photo stabilization of Thermoplastic Polymers. Lambert Academic Publishing, Germany.

Hamid, S.H., 2000. Handbook of Polymer Degradation. Ed. Techniques Ingénieur. Marcel Dekker Inc, New York.

Aliyu, H.N. and H.J. Abdullahi, 2009. Synthesis and Characterization of Manganese(II), Cobalt (II), Nickel (II) and Copper (II) N, N' -Bis(Benzoin)Ethylenediiminato Complexes. Bayero. Journal of Pure and Applied Sciences, 2(2): 110-112.

Nuha, H. Al-Saadawy and Firas F. Alyassin, 2016. Schiff base[(Z)-2-((2-Aminoethyl)Imino)-1,2Diphenylethanol)]and Their Metal Complexes, Synthesis and Characterization. American Scientific Research Journal for Engineering, Technology, and Sciences, 18(1): 271-278.

Bottino, F.A., A.R. Cinquegrani, G. Di Pasquale, L. Leonardi and A. Pollicino, 2004. Chemical Modifications Mechanical Properties And Surface Photo-Oxidation of Films of Polystyrene (PS). Polymer Testing, 23(4): 405-411.

-Shriner, R.I. and C.K. Hermann, 2004. Spectroscopic Techniques for Organic Chemistry.John Wiley \&Sons, N. Y.

Harris, W and B. Kratochvil, 1981. An Introduction to Chemical Analysis, New York, pp: 572.

usop, R., N. Shalan, A. Ahmed, D. Derawi, A. Al-Amiery, A. Kadhum, R. Haddad and E. Yousif, 2014. Photochemical and Physical Study of PVC- Amines Polymers. Australian Journal of Basic and Applied Science., 8(17): 394-401.

Gugumns, F., 1979. Development in Polymer Photo stabilization. (G. Scott, ed.), Applied Science Publisher Ltd, London, pp: 261-272.

Sabaa, M., E. Oraby, A. Abdel Naby and R. Mohamed, 2006. N-Phenyl-3-substituted- 5-pyrazolone Derivatives as Organics Stabilizers for Rigid Poly(Vinyl Chloride) Against Photo degradation. Journal of Applied Polymer Science., 101: 1543-1555.

Braun, D., S. Rabie, N.M. Khaireldin and Abd El-Ghaffar, 2011. Preparation and Evaluation of Some Benzophenone Ter polymers as Photo stabilizers for Rigid PVC, J. Vinyl Addit. Technol., (17):147-155. 